\title{
Phytochemical Screening and in Vitro Evaluation of the Antibacterial Activity of Organic Extracts from the Root Bark of Cussonia arborea (Araliaceae)
}

\author{
Luciane Marlyse Moungang (Correspondence) \\ Laboratory of Hydrobiology and Environment, Department of Animal Biology and \\ Physiology, Faculty of Sciences, University of Yaounde I, Cameroon \\ Lazare Sidjui Sidjui \\ Institute of Medical Research Plant Studies, Yaounde, Cameroon
}

Hervé Narcisse Bayaga

Department of Pharmacognosy and Pharmaceutical Chemistry, Faculty of Medicine and Biomedical Sciences, University of Yaounde I, Cameroon

\section{Josséline Ndambedia Mfouapon}

Department of Pharmacognosy and Pharmaceutical Chemistry, Faculty of Medicine and Biomedical Sciences, University of Yaounde I, Cameroon

\section{Ondoua Nguélé}

Department of Pharmacology and Traditional Medicine, Faculty of Medicine and Biomedical Sciences, University of Yaounde I, Yaounde, Cameroon

\section{Hortense Kamga Gonsu (Correspondence)}

Laboratory of Bacteriology, Center University Teaching Hospital of Yaounde, P Faculty of Medicine and Biomedical Sciences, University of Yaounde I, Cameroon 
Bathélemy Ngameni

Department of Pharmacognosy and Pharmaceutical Chemistry, Faculty of Medicine and Biomedical Sciences, University of Yaounde I, Cameroon

Received: September 9, 2021 Accepted: October 16, $2021 \quad$ Published: October 16, 2021

Doi: 10.5296/jab.v9i2.19102

URL: https://doi.org/10.5296/jab.v9i2.19102

\begin{abstract}
Objective: To assess the usefulness of Cussonia arborea in the treatment of bacterial infectious diseases.
\end{abstract}

Study Design: Experimental analytical study.

Place and Duration of Study: The study was done in the Laboratory of Hydrobiology and Environment of the Faculty of Sciences, University of Yaounde1; the Bacteriology Laboratory of the Yaoundé University Teaching Hospital; the Laboratory of Pharmacognosy and Pharmaceutical Chemistry of the Faculty of Medicine and Biomedical Sciences and the Laboratory of Organic Chemistry of the Faculty of Sciences of the University of Yaoundé I. The study was done in a period of six months.

Methodology: The root bark of Cussonia arborea was collected in the village Yambéta (Central Region, Cameroon), dried and pulverized. Thereafter, two extractions were performed by embedding $200 \mathrm{~g}$ of powder in $2000 \mathrm{~mL}$ of $96^{\circ}$ ethanol, and in a hydro-ethanolic mixture $(30 / 70, v / v)$, respectively. Qualitative phytochemical screening was performed. Minimum inhibitory and bacterial toxicity were determined by macro-dilution in liquid medium on Staphylococcus aureus, Salmonella sp, Shigella sp and Proteus mirabilis provided by the Laboratory of Hydrobiology and Environment of the Faculty of Sciences, University of Yaounde1 and the Bacteriology Laboratory of the Yaoundé University Teaching Hospital.

Results: Phytochemical screening revealed the presence of polyphenols (flavonoids, and tannins), alkaloids, quinones, saponins and, cardiac glycosides. However, coumarins were absent in the two extracts. The minimum inhibitory concentrations of the extracts ranged from 25 to $100 \mathrm{mg} / \mathrm{mL}$, and the minimum bactericidal concentrations from 25 to $200 \mathrm{mg} / \mathrm{mL}$. The ethanolic extract was bactericidal against Proteus mirabilis and Staphylococcus aureus, but bacteriostatic against Salmonella sp and Shigella sp. The hydro-ethanolic extract was bacteriostatic against Shigella sp and bactericidal against the other strains.

Conclusion: The groups of polyphenols, alkaloids, quinones, saponins and, cardiac glycosides contained in the two extracts can justify the antibacterial activity observed against Staphylococcus aureus, Salmonella sp, Shigella sp and Proteus mirabilis.

Keywords: Cussonia arborea, Phytochemical screening, Antibacterial properties 


\section{Introduction}

According to the World Health Organization (WHO), infectious diseases are responsible for 14.7 million deaths worldwide (Madrid et al., 2017). Diarrhoeal diseases cause the death of 751 thousand children each year in the world and are among the main causes of infant mortality and morbity with a prevalence of $13.6 \%$ in Cameroon [2]. The etiology of diarrhoea can be bacterial and the germs often responsible are Salmonella $s p$, Shigella $s p$ and Staphylococcus aureus (Levoa et al., 2015; UMVF, 2010). The management of infectious diseases is based on pharmacotherapy that offers several families of antibiotics with different spectrums and mechanisms of action (Schwarz et al., 2017). However, the medical community is faced with a growing increase in antibiotic resistance, which considerably limits patient management (Diallo et al., 2019; Duval, 2019). Therefore, traditional medicine is usually the alternative treatment allowing the discovery of new and more effective drugs (Titanji et al., 2008). The WHO recognizes that certain plant-based medicines can replace certain so-called conventional medicines (OMS, 2013). In this process of exploring the therapeutic potential of the traditional, it was observed in Yambeta, a village in Cameroon, that traditional practitioners use the bark of the roots of Cussonia arborea for several therapeutic purposes, particularly in the treatment of diarrhoea. It was hypothesised that extracts of this plant may relieve patients suffering from diarrhoea of bacterial origin. To this end, we proposed to characterise the phytochemical composition of $C$. arborea roots and to evaluate its antibacterial activity in order to justify its use in traditional medicine.

\section{Materials and Methods}

\subsection{Study Area}

The study took place in the Laboratory of Pharmacognosy and Pharmaceutical Chemistry of the Faculty of Medicine and Biomedical Sciences, the Laboratory of Organic Chemistry of the Faculty of Sciences of the University of Yaoundé I, the Laboratory of Hydrobiology and Environment of the Faculty of Sciences of the University of Yaounde I and the Laboratory of Bacteriology of the Yaoundé University Hospital Center (YUHC). The study was authorized by the Institutional Research Ethics Committee of the Faculty of Medicine and Biomedical Sciences (N²08/UYI/FMSB/VDRC/DAASR/CSD).

\subsection{Plant Material}

The plant material consisted of C. arborea root bark collected in Yambeta, a locality in the Mbam and Inoubou Division in the Central Region of Cameroon. It was identified at the National Herbarium in Yaoundé under $N^{\circ} 11087 \mathrm{SRF} / \mathrm{Cam}$. The plant was dried in a rack for 21 days and then pulverized.

\subsection{Biological Material}

Bacterial strains of Staphylococcus aureus, Salmonella sp, Shigella sp and Proteus mirabilis provided by the Laboratory of Hydrobiology and Environment of the Faculty of Science of the University of Yaounde I and the Laboratory of Bacteriology of the (YUHC) were used.

\subsection{Plant Extraction}

Two extractions by maceration for 72 hours were performed. The first one by homogenizing $200 \mathrm{~g}$ of C. arborea root bark powder in $2000 \mathrm{~mL}$ of $96^{\circ}$ ethanol. The second extraction was carried out by embedding the same mass of powder in the same volume of a hydro-ethanol 
mixture $(30 / 70, v / v)$. After filtration with the Whatmann paper $n^{\circ} 1$, the macerate obtained was dried in an oven at $40^{\circ} \mathrm{C}$.

\subsection{Phytochemical Screening}

The phythochemical screening was perfomed according to Sofowora et al. (1993).

\subsection{Antibacterial Activity}

\subsubsection{Preparation of Bacterial Inocula}

The bacterial incula were prepared according to the recommendations of the Clinical and Laboratory Standard Institute (CLSI) (2012).

\subsubsection{Preparation of Stock Solutions of Extracts}

In particular, the hydro-ethanolic and ethanolic extracts were dissolved in dimethylsulphoxide $1 \%$. The concentration of the stock solutions was prepared at 400 $\mathrm{mg} / \mathrm{mL}$.

2.6.3 Determination of the Minimum Inhibitory and Bactericidal Concentrations of Extracts It was carried out according to liquid macro-dilution as described by CLSI (2012).

\subsection{Statistical Analysis}

Data were analyzed using Word and Excel 2016 (Microsoft Office 2016, USA). Describe statistics involved the presentation of data as the percentage in tables and graph and as mean \pm standard errors on the mean (SEM) for the variables analyzed.

\section{Results}

Table 1. Major groups of secondary metabolites present in C. arborea root bark extracts

\begin{tabular}{lll}
\hline Secondary metabolites & Hydro-ethanolic extracts & Ethanolic extracts \\
\hline Alkaloids & + & + \\
Polyphenols & + & + \\
Flavonoids & + & + \\
Tannins & + & + \\
Saponosid & + & - \\
Steroids et triterpens & + & + \\
Anthocyanins & + & + \\
Coumarins & - & - \\
Quinones & + & + \\
Cardiac glycosides & + & + \\
+ Present; - Absent & & \\
\hline
\end{tabular}

The hydro-ethanolic extract showed the presence of all tested secondary metabolite groups except coumarins. The ethanolic extract showed the absence of saponosides and coumarins. 
3.2 Antibacterial Activity

Table 2. Inhibition parameters of C. arborea root bark extracts.

\begin{tabular}{lllllll}
\hline Microorganisms & \multicolumn{3}{l}{ Ethanolic extract } & \multicolumn{2}{l}{ Hydro-ethanolic extract } \\
\cline { 2 - 7 } & CMI & CMB & CMB/CMI & CMI & CMB & CMB/CMI \\
Proteus mirabilis & 100 & 200 & 2 & 100 & 200 & 2 \\
Staphylococcus aureus & 25 & 25 & 1 & 100 & 100 & 1 \\
Shigella sp & 25 & 100 & 4 & 50 & 200 & 4 \\
Salmonella sp & 50 & 200 & 4 & 100 & 200 & 2 \\
\hline
\end{tabular}

Ethanolic and hydro-ethanolic extracts of $C$. arborea root bark were active on the different bacterial strains tested. The minimum inhibitory concentrations were between 25 and 100 $\mathrm{mg} / \mathrm{mL}$, and the minimum bactericidal concentrations between 25 and $200 \mathrm{mg} / \mathrm{mL}$. The ethanolic extract was found to be bactericidal on Proteus mirabilis and Staphylococcus aureus, but on Salmonella sp and Shigella sp it was bacteriostatic. The hydro-ethanolic extract was bacteriostatic against Shigella sp and bactericidal against the other strains.

\section{Discussion and Conclusion}

The present study focused on the phytochemical characterization and evaluation of antimicrobial activity of the hydro-ethanolic and ethanolic extracts of the root bark of $C$. arborea. The phytochemical analysis performed on the extracts showed that the hydroethanolic extract and the ethanolic extract of $C$. arborea root bark have similar compounds. However, saponins were higher in the ethanolic extract than in the hydro-ethanolic extract, results in agreement with findings by Tabouguia et al. (2014) who did not observe the presence of saponins in the hydro-ethanolic extract. This difference might be justified by the fact that the latter used methanol as extraction solvent. Besides, in comparison to the results obtained by Tabouguia et al. (2014), alkaloids were revealed in both extracts. Tabouguia et al. had indeed used the Meyer test to measure alkaloid levels while in our study, the Hager and Draggendorf tests were used.

The second objective of the present work was to evaluate the antibacterial activity of ethanolic and hydro-ethanolic extracts of $C$. arborea root bark. These extracts were all active against S. aureus, Salmonella sp, Shigella spp and P. mirabilis. The phytochemical composition of the extracts may justify this activity. Many studies have shown that tannins, steroids, flavonoids, quinones, saponins, and terpenoids possess antimicrobial properties (Salihu, 2008; Cowan, 1999). Indeed, these secondary metabolites act through different mechanisms of action in infectious diseases. For instance, Tannins act by depriving iron (Scalbert, 1991), alkaloids intercalate into DNA and inhibit its synthesis. Compean et al. (2014) had shown that steroids, saponins and tannins present in plant extracts may justify their bactericidal potential, findings that are consistent with the results obtained in our study. 


\section{Strength of the study}

From a pharmacological point of view, this study justifies the traditional use of Cussonia arborea in the treatment of diarrhoea.

\section{Weakness of the study}

This study did not identify the group of secondary metabolites responsible for the antibacterial activity and did not provide any toxicological data of the plant extracts.

Disclosure statement: The authors declare no conflict of interest.

Funding: This research was supported by the NAPRECA through ISP Grant under the International Programme in Chemical Sciences (IPICS).

\section{Acknowledgments}

BN acknowledges NAPRECA for a research financial support to the NAPRECA- Cameroon through ISP Grant under the International Programme in Chemical Sciences (IPICS). Thanks are also due to the Bacteriology Laboratory of the Yaoundé University Hospital Centre as well as the Hydrobiology and Environment laboratory and the Organic Chemistry laboratory of the Faculty of Sciences; University of Yaounde I. The authors are also grateful to the Laboratory of Pharmacognosy and Pharmaceutical Chemistry of the Faculty of Medicine and Biomedical Sciences, University of Yaounde I, Cameroon for research facilities and important support with the experimental equipment.

\section{References}

Clinical and Laboratory Standards Institute (CLSI). (2012). Methods for Dilution Antimicrobial Susceptibility Tests for Bacteria That Grow Aerobically. Appr Stand Ninth Ed, $32(2), 88$.

Compean, K., \& Ynalvez, R. (2014). Antimicrobial activity of plant secondary metabolites: A review. Res J Med Plant, 8(5), 204-13. https://doi.org/10.3923/rjmp.2014.204.213

Cowan, M. (1999). Plant products as antimicrobial agents. Clin Microbiol Rev, 12, 564-82. https://doi.org/10.1128/CMR.12.4.564

Diallo, O., Baron, S., Jimeno, M-T, Abat, C., Dubourg, G., \& Chaudet, H. (2019). Mortality in bacteremia caused by Difficult to Treat Resistance (DTR) bacteria. Med Infect Dis, 49(4), 48. https://doi.org/10.1016/j.medmal.2019.04.123

Duval, M. (2019). Cossart P. A new mechanism of antibiotic resistance - Ribosome recycling. med/sci, 35(8-9), 613-5. https://doi.org/10.1051/medsci/2019117

Levoa, E. F., Fokunang, N. C., Tchuenguem, F. F., Nolna, D., Boula, A., \& Ngum, N. V. (2015). Epidémiologie moléculaire du rotavirus du groupe A associé aux gastroentérites chez les enfants de moins de 5 ans dans la ville de Yaoundé (Cameroun). Int J Biol Chem Sci, 9(5), 2561-2573. https://doi.org/10.4314/ijbcs.v9i5.25

Madrid, L., Seale, A. C., Kohli-Lynch, M., Edmond, K. M., Lawn, J. E., Heath, P. T., \& Madhi, S. A. (2017). Infant GBS Disease Investigator Group, Infant Group B Streptococcal Disease Incidence and Serotypes Worldwide Systematic: Review and Meta-analyses. Clin Infect Dis, 65(S2), S160-S172. https://doi.org/10.1093/cid/cix656

Nguendo, Y. H. B. Landforms and diarrheal diseases in Yaoundé (Cameroon): A medical geomorphology approach in a tropical urban setting. Can Journ Trop Geo, 1(2), 24-36. 
Organisation Mondiale de la Santé (OMS). (2013). Stratégie pour la médecine traditionnelle 2014-2023.

Salihu, L., \& Garba, S. (2008). Preliminary investigation of the bioactive constituents of some medicinal plants. Biol Environ Sci J Trop, 5(1), 164-8.

Scalbert, A. (1991). Antimicrobial properties of tannins. Phytochem, 30(12), 3875-83. https://doi.org/10.1016/0031-9422(91)83426-L

Schwarz, S., Loeffler, A., \& Kadlec, K. (2017). Bacterial resistance to antimicrobial agents and its impact on veterinary and human medicine. Adv Vet Derm, Torres SMF, Roudebush P (Eds.). John Wiley \& Sons: Oxford; 95-110. https://doi.org/10.1002/9781119278368.ch5.1

Sofowora, A. (1993). Medicinal plants and traditional medicine in Africa. J Wil S LTD.

Titanji, V. P. K., Zofou, D., \& Ngemenya, M. N. (2008). The antimalarial potential of medicinal plants used for the treatment of malaria in Cameroonian folk medicine. Afr Journ Trad Compl Alter Med, 5(3), 302-21.

Université Virtuelle Médicale Francophone (UMVF). (2010). Les toxi-infections alimentaires collectives: aspectscliniques et épidémiologiques. Collège des Enseignants de Nutrition, support de cours.

\section{Copyright Disclaimer}

Copyright reserved by the author(s).

This article is an open-access article distributed under the terms and conditions of the Creative Commons Attribution license (http://creativecommons.org/licenses/by/4.0/). 